\title{
Converting failed financial institutions into mutual organisations
}

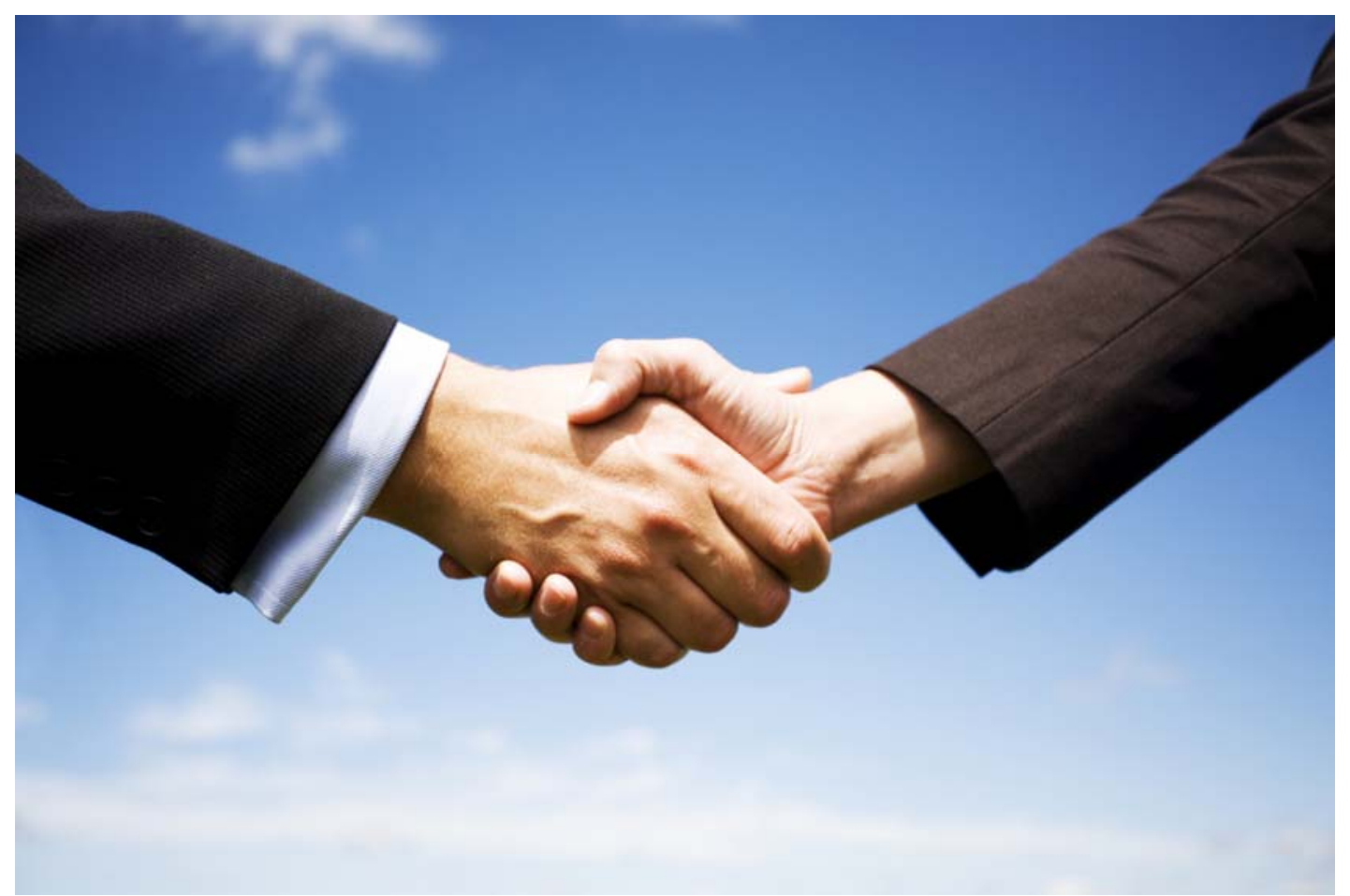

A Report from The Oxford Centre for Mutual \& Employee-owned Business Kellogg College, University of Oxford

Published for The Building Societies Association 
Preface by Adrian Coles, Director-General, BSA 2

Foreword by the Rt Hon John McFall MP 3

Executive Summary 4

1 Introduction 6

2 The economics of mutuals 9

3 Remutualisation: a systemic strategy after the crisis 12

4 The politics of remutualisation 17

5 Financial issues 24

6 Legal and governance issues 26

7 Conclusions 30

Appendix: The demutualisations of the 1990s 33

Bibliography 35

List of Authors $\quad 37$

Acknowledgements $\quad 38$

About the Oxford Centre for Mutual and Employee-owned Business 39 


\section{Preface}

\section{By Adrian Coles, Director-General, Building Societies Association}

The world of finance has changed profoundly over the last two years. Some ideas that came to be regarded as the "new truths" in finance have been found wanting, while some "old certainties" have re-established themselves. One of the old certainties that some of us had never forgotten is the enduring attraction of the mutual model for offering financial services to customers. Lower risk, member involvement in decision-making, organisational diversity and better customer service seem to be just what the market needs at the moment. Mutuals provide all of these.

With these points in mind the BSA is delighted to publish this new research from the Oxford Centre for Mutual and Employee-owned Business. Everyone in the mutual sector will have different ideas on the exact mechanism for remutualising Northern Rock, and the BSA does not necessarily endorse every detailed point in this report; there will be widespread agreement, however, about the general direction in which we should be going. This report provides us with a fine starting point for a debate that should be joined by everyone with an interest in developing and improving the provision of financial services to consumers in the UK. 


\section{Foreword}

\section{By the Rt. Hon. John McFall MP}

This research paper is a timely contribution to the debate on the future of our financial services sector.

The origins of what is an international banking crisis are many and varied, including low real interest rates, a search for yield, apparent excess liquidity and a misplaced faith in financial innovation. These ingredients combined to create an environment rich in overconfidence and over-optimism amongst the leadership of financial institutions.

I am in no doubt that those banks which failed were the principal authors of their own demise; bankers made an astonishing mess of the financial system. However, it was a failure not only of individual banks but also of the supervisory system designed to protect the public from systemic risk. Governments, politicians, regulators and central bankers in the UK and across the world must also share responsibility for sustaining the illusion that banking growth and profitability would continue to rise inexorably.

What we need now is substantial change to the remuneration practices, corporate governance and culture of banking. I would hope that the nature of banking would change of its own accord in response to the crisis, but I fear that as soon as public and media attention turns away, we may see a return to 'business as usual.' This absolutely must not happen; we have before us a once in a generation opportunity to fix the financial system, which we ought to seize.

Some lessons can be learned by banks from building societies. Certain features of the building society model, including the comparatively low reliance on wholesale funding, the relative simplicity of operations and the focus on the protection of members rather than the (sometimes excessively short-termist) satisfaction of shareholders, have left most building societies better equipped to defend against the shockwaves of the current crisis.

If ever there was a time for an expanded mutual sector, it's now. We desperately need to restore faith in financial services in this country.

The ideas discussed in this publication provide a fertile area for debate and the Government should carefully consider the potential for returning Northern Rock to the mutual sector. 


\section{Executive Summary}

There are three key reasons for creating an enhanced role for mutual building societies:

i. Building societies are less prone than banks to pursue risky speculative activity;

ii. A mixed system is likely to produce a more stable financial sector; and

iii. A stronger mutual sector will enhance competition within the financial system.

The systemic advantage of remutualisation would be greater than any benefit to be derived from a quick sale for cash of the Government's capital holding in Northern Rock.

The banking crisis has highlighted the importance to the UK economy of retaining diverse models of financial service providers. And while mutuals were affected by the recession, they were not themselves responsible for causing the recession, as was the case with the private banking sector. The Government needs to secure both a financial return and an acceptably low level of overall financial and economic risk for the taxpayer. If there is a trade-off, then the long-run benefits of financial sustainability and reduced risk, plus enhanced competition, need to be given proper weighting.

Any remutualisation need not imply precisely the same mutual model as currently exists even though the basic philosophy of mutuality is retained: just as we argue the case for 'bio-diversity' within the financial sector generally, there can also be different approaches within the basic mutual model.

\section{Financial issues}

For any failed financial institutions to be transferred out of public ownership would most likely require the 'good bank' - to be transferred - to be split from the 'bad bank' which would need to be managed out by specialists for UKFI, minimising taxpayer losses. The good bank would hold deposits and start to increase its mortgage lending. Were the failed financial institution to be remutualised, they could also provide the infrastructure for central services for smaller mutuals - lowering their costs and helping them to compete, thus further strengthening the resilience and stability of the country's financial services sector. (This report focuses in particular on the case of Northern Rock, which we regard as the most suitable candidate for remutualisation, and whose disposal is under current consideration, but the analysis applies more widely.)

Since the Government's senior debt could, and should, be repaid over time under any ownership scenario, the main financial issue is realising the equity value of Northern Rock for the taxpayer. It is unclear how much this value is, but certainly considerably less than the amount of the senior debt; and an early trade sale, at today's prices and in a rising market, would almost certainly prove a poor bargain. Given that remutualisation would strengthen competition and create a more diversified financial sector, it could be expected to generate an advantage to the taxpayer over the long run in excess of the immediate benefit of any capital proceeds in the short run. 
The Financial Services Authority announced earlier in 2009 a new instrument for the building society sector - profit participating deferred shares or PPDS - allowing capital to be provided in a way that carries modest servicing costs to begin with but which can deliver a fair overall return in the long term. A capital instrument of the PPDS type may help restructure some of the existing capital, and a more attractive version of PPDS could be issued to UKFI as consideration for its equity, and either held for income, redeemed, or sold in due course into the market - which may be much quicker than just waiting for retained profits to be generated in sufficient quantity.

The assets of any remutualised entity should be locked-in for the purpose intended: namely to create a strong mutual underpinning to the UK financial services sector, create a diverse ownership and behavioural structure, promote competition, diversify the economy geographically as well as by ownership and governance structures, reduce risk of financial crises and economic recession, and promote community benefit.

It has to be accepted that this low-risk model will be a relatively low-return business, especially if the remutualised businesses are required to make future payments to the taxpayer. Indeed, it has been suggested that this is precisely what we need to aim for, to create the situation where 'Banking becomes a low risk, low return business'.

\section{Governance}

There are several options for how membership could be offered; it could be held by existing and new customers of the previously failed financial institution (for example Northern Rock), and would accrue benefits as long as the members trade with the mutual. Crucially, it would be clear up front that it did not confer an individual proprietary stake in the business: and the underlying assets could not be demutualised.

HM Treasury/UKFI will be considering how to dispose of Northern Rock. It could be sold in a trade sale, floated as an independent entity, or more imaginatively, converted to a mutual. Northern Rock, an ex-mutual, remains a relatively straightforward savings and mortgage business, particularly suitable for returning to mutual ownership, which would:

i. Avoid selling the holding into a depressed market, losing value for the taxpayer;

ii. Create a stable financial services provider, constrained from previous mistakes;

iii. Promote competition in the financial system; and

iv. Support diversity in financial institutions across the financial services sector.

The Government's ambitions to relinquish its ownership of Northern Rock while boosting competition in the financial services sector can best be achieved through a remutualisation. This would require UKFI conducting a full feasibility study of the potential for a Northern Rock mutual, based on the ideas outlined in this Report.

This Report sets out a clear and achievable route map from here towards a more competitive and sustainable financial services sector. The next step would be a UKFI feasibility study of remutualising Northern Rock. 


\section{$1 \quad$ Introduction}

In the wake of the financial crisis, the government's proposals to reinvigorate competition in the banking sector include 'supporting competition and choice through diversity, most importantly through maintaining a strong mutually-owned financial sector'. This reflects a consensus across the major political parties for diversity of corporate form within financial services, with a strong mutual sector. The cross-party support for the Building Societies (Funding) and Mutual Societies (Transfers) Act 2007 had already demonstrated this broad political consensus. The case has become even more compelling given the performance of the private banking sector since 2007 . In this context, there are three key reasons for creating an enhanced role for mutual building societies:

i. The ownership structure, regulation and traditional business model of mutual building societies (particularly the dominance of retail funding) makes them less prone to risky speculative activity than is the case with shareholder-owned banks;

ii. A mixed system of different corporate structures is likely to produce a more stable financial system; and

iii. A larger critical mass of mutuals is likely to enhance competition in the financial system.

The immediate issue is whether the failed financial institutions that were taken into public ownership - most obviously Northern Rock - could be re-launched as mutuals rather than as plcs. Should these former mutuals - which were demutualised to the personal financial gain of some, but at a cost to the taxpayers who subsequently bailed out the failed banks - be remutualised? This would pose logistical challenges. Before consideration is given to such issues, it is necessary to consider the strength of the case for such a remutualisation bearing in mind that Northern Rock has a formal commitment to repay Government loans of $£ 14.5$ billion, ${ }^{2}$ quite apart from any realisation of the public investment in its capital. ${ }^{3}$

The mutual building society model has various beneficial features and these clearly contributed to the success of the sector in the UK up until the move to demutualisation during the 1990s. The focus of the current Report is not, however, on the range of benefits that the mutual model provides in terms of stakeholder engagement and community involvement, which has been analysed elsewhere, ${ }^{4}$ but rather to consider whether there would be a systemic advantage for the UK economy in having a

\footnotetext{
1 HM Treasury White Paper, Reforming Financial Markets, July 2009.

2 Source: Northern Rock interim results Aug 2009.

3 The UK Government's proposals for the restructuring of Northern Rock were summarised in redacted form by the European Commission in their consultation on the resulting state aid issue:

http://eur-lex.europa.eu/LexUriServ/LexUriServ.do?uri=OJ:C:2009:149:0016:0026:EN:PDF

4 See for example Cook, Deakin, Michie and Nash (2003) and Michie and Blay (2004).
} 
strengthened mutual sector. Drake and Llewellyn (2001) and Llewellyn (2009c) analyse this systemic dimension to the case for mutuality rather than appealing to the merits of the mutual model per se. However, this is not to argue that there is no intrinsic case. It can be argued that mutuals have a potential inherent 'efficiency advantage' in respect of financial intermediation, and a particular advantage when long term customer relationships are involved. Kay (1991), for example, argues that:

'The special value of mutuality rests in its capacity to establish and sustain relational contract structures. These are exemplified in the most successful mutual organisations, which have built a culture and an ethos among their employees and customers, which even the best of plc structures find difficult to emulate.' (Kay, 1991, p. 317)

The prevalence and long history of mutuals and co-operatives in the financial sectors of many economies, together with their relative scarcity in non-financial sectors, suggests that mutuality may be particularly suited to the provision of financial services, and most especially those related to longer term contractual relationships such as mortgages, savings and life assurance. This may be due to an inherent 'efficiency advantage' in this area and the greater ability of financial - as opposed to non-financial - mutuals to address any inherent agency problems.

Notwithstanding the particular merits of the mutual model, we are interested in whether there is a strong case in terms of systemic economic (and possibly social) advantages. This brings us into the area of externalities. Section 3 of the Report, below, considers three main issues:

i. how the building societies performed in the context of the global financial crisis;

ii. the contrasting business models of converted building societies versus those that remained as mutual building societies; and

iii. the opportunities created for the remutualisation of Northern Rock.

Several themes emerge:

i. With a few notable exceptions (of which Dunfermline was the extreme case) most building societies have weathered the global financial crisis reasonably well and more successfully than many banks - and in particular, more successfully than those societies that converted.

ii. There are analytical reasons for this in terms of regulation and the implications of the mutual model: with some exceptions, and in contrast to some of their bank competitors, building societies have tended to stick to the traditional model of the 'banking' firm with a reliance on retail deposits, limited use of wholesale market funding, and limited use of credit risk shifting derivatives and other instruments.

iii. Not one of the converted building societies has survived as an independent financial institution and two (Northern Rock and Bradford \& Bingley) have been

$5 \quad$ See also Cook et al. (2003) who report survey evidence indicating high levels of trust in building societies from their members. 
forced into public ownership; a third (Halifax) is part of a group $43 \%$ owned by the State.

iv. The key reason for the different performance of banks and building societies lies in their respective business models and in particular (but not only) with respect to funding strategies. Some building societies that converted to bank status subsequently adopted a business model (heavy reliance on securitisation and wholesale funding) that would not have been legally possible had they remained as mutual building societies. To a large extent it has been this business model that undermined the converted building societies.

v. The remutualisation of Northern Rock would create a mutual sector with greater critical mass, thus enhancing the competitive pressure on shareholder owned banks and creating a more diversified financial services sector.

vi. Such systemic advantages, which would accrue to the population at large, would be worth paying for in terms of the tax-payer deferring the cashing-in of the public investment in Northern Rock.

Above all, the mutual model remains a viable governance model in the financial system: it is not to be regarded as an aberration from the plc norm. On the basis of theoretical analysis and recent experience, there is no presumption that the typical Anglo-Saxon governance model is best suited for all types of financial institution. On the contrary, there would be advantages in having a stronger mutual sector, not only because their ownership and governance structures create less incentive than is the case with shareholder-owned banks to pursue risky speculative activities, but also because of the systemic advantage in having a mixed system of models. 
Co-operative banks, credit unions and other financial mutuals play an important and growing role in most European economies. It is the UK that is out of step, having travelled in the opposite direction since the demutualisation of the 1990s. Five EU member states have more than a 40 percent share of co-operative or mutual banks in terms of branch networks, and these include France and Germany. These figures come from an IMF Working Paper by Hesse and Čihák (2007) who also report that for their sample of countries, the market share of co-operative and mutual banks in terms of total banking sector assets increased from about 9 per cent in the mid-1990s to about 14 per cent in 2004. (In the UK the Building Societies Association reports that building societies have about 20 per cent of both the retail deposit market and of outstanding residential mortgage loans.) Hesse and Čihák's conclusion is that co-operative banks are more stable than commercial banks, and have advantages for consumers. ${ }^{6}$

\subsection{Risk and diversification in mutuals}

In many countries, mutual (and other non-proprietary) financial institutions tend on the whole to be specialised and relatively low-risk institutions, with the mortgage, savings and life assurance markets providing prime examples. While it is clear that mutual financial institutions have traditionally been narrowly focused and (with some recent exceptions) relatively low-risk institutions as a direct result of restrictive regulation, financial mutuals would tend to adopt this profile even in the absence of such regulation. With respect to risk, this reflects the fundamental characteristics of mutuals, specifically their lack of access to significant external sources of capital, and being owned by saver members rather than external shareholders. The knowledge that capital cannot easily be replaced following the generation of significant losses is likely to induce mutual financial institutions to adopt a relatively low-risk profile. ${ }^{7}$

\subsection{Systemic dimension: bio-diversity}

Mutuals do not pay dividends to external shareholders. Instead, financial success can be used to reduce the margin between the interest rate they charge to borrowers and what they pay to savers (on which, see Drake and Llewellyn, 2001). This 'margin advantage' of mutual financial institutions due to them not having to pay dividends on external capital, and the systemic advantages of a mixed financial structure, represent economic and welfare benefits from having a mutual building society sector. There is a powerful systemic interest in sustaining a strong mutual sector and, therefore it is a legitimate public policy issue. There are several key issues in this regard which point to the benefits that might flow from re-mutualisation:

\footnotetext{
6 See also Hans Groeneveld and Bouke de Vries (2009).

$7 \quad$ Hansmann (1996) and Chaddad and Cook (2004) find that mutual financial institutions in the United States tend to adopt less risky strategies than demutualised ones.
} 
i. The effect that a strong mutual sector has in enhancing competition because mutuals adopt a different business model compared with banks: for this to be an effective enhancement to competition a strong critical mass of mutuals is needed.

ii. Because mutuals are not owned by investment institutions, they are not subject to the short-termist pressure of the capital market.

iii. Most building societies (and many mutual and co-operative banks in other European countries) are locally or regionally based and have a particular focus and expertise on their communities. ${ }^{8}$

iv. The advantage through having a mix of institutions with different portfolio structures with the potential to reduce overall systemic risk because institutions are not homogeneous. The more diversified is a financial system in terms of size, ownership and structure of businesses, the better it is able to weather the strains produced by the normal business cycle, in particular avoiding the bandwagon effect, and the better it is able to adjust to changes in consumer preferences. As put in a Financial Times editorial (27 April 1999):

'... a pluralist approach to ownership is conducive to greater financial stability. With their contrasting capital structures, banks and building societies balance their risks and loan portfolios differently. Systemic risk is therefore reduced'.

v. Though there have been recent exceptions with some building societies expanding excessively into commercial property loans, mutuals tend to adopt a lower risk profile because their main source of capital is that generated within the business. Unlike with a plc, capital that is destroyed through, for instance, bad lending cannot easily be replaced by raising new capital in the market.

vi. In an uncertain market environment, diversity has advantages as it cannot be predicted which form of corporate structure is best suited to all particular circumstances. As put by Ayadi et al (2009) the case for diversity includes: 'reducing institutional risk, defined as the dependence on a single view of banking that may turn out to have serious weaknesses under unexpected conditions such as the current crisis'.

While not explicitly discussing mutuals, the Executive Director for Financial Stability at the Bank of England, Andrew Haldane, has set out clearly the beneficial effects of diversity for the robustness of financial networks:

Within the financial sector, diversity appears to have been reduced for two separate, but related, reasons: the pursuit of return; and the management of risk. The pursuit of yield resulted in a return on equity race among all types of financial firm. As they collectively migrated to high-yield activities, business strategies came to be replicated across the financial sector. Imitation became the sincerest form of flattery.

8 Even the UK's large building societies with a national franchise are headquartered outside London, so reducing the concentration of financial resources and employment in the City. 
So savings co-operatives transformed themselves into private commercial banks. Commercial banks ventured into investment banking. Investment banks developed in-house hedge funds through large proprietary trading desks. Funds of hedge funds competed with traditional investment funds. And investment funds - pension, money market mutual, insurance - imported the risk the others were shedding...

Through these channels, financial sector balance sheets became homogenised. Finance became a monoculture. In consequence, the financial system became, like plants, animals and oceans before it, less disease-resistant. When environmental factors changed for the worse, the homogeneity of the financial eco-system increased materially its probability of collapse. (Haldane, 2009a, pp. 18-19)

\subsection{Enhancing diversity and competition}

The case for a financial system being populated by a diversity of organisational forms is as significant as the merits and drawbacks of each particular model. Cuevas and Fischer (2006), for example, argue that a financial system that presents a diversified institutional structure, including institutional types, will be more efficient in promoting economic growth and reducing poverty. It is in this respect that a significant public policy issue arises. A financial system populated by a diversity of ownership structures is likely to be more competitive and systemically less risky than one populated by either all plcs or all mutuals.

Much was lost to the British financial system by the demutualisation of building societies, both in terms of the intrinsic merits of the mutual model, and in terms of systemic diversity and competition. A former Non-Executive Director of the Halifax when a mutual has argued: 'With hindsight, [conversion] was a mistake that damaged a fine business' (Kay, 2008). More generally, The Times in a leading article has also questioned the wisdom of de-mutualisation:

'Of itself, the move to plc status was harmless. But it had two dangerous elements. It liberated those once cautious building society bosses to diversify into new activities, and provided them with the capital to do so. It also loaded them with remuneration packages so poorly structured that they encouraged short-term recklessness.'

Given the advantages of having a system that is mixed and has a critical mass of mutual institutions, the important question is whether there could be a re-mutualisation of previously converted building societies. This is a relevant issue in the case of Northern Rock, currently in State ownership. While there would be logistical problems to resolve, the mutualisation of the bank is an option that should be seriously considered because this would bring both systemic benefit and advantages to consumers. 


\section{Remutualisation: a systemic strategy after the crisis}

\subsection{How building societies performed in the crisis}

It is not to be expected that building societies would be immune from the enormity of the banking crisis: collateral damage was inevitable. ${ }^{9}$ Nevertheless, the mutual building societies were generally less scathed by the financial crisis than were banks in general and demutualised building societies in particular. Indeed, converted building societies proved to be more vulnerable the further they moved away from their traditional model. As argued in a leading article in The Times ( $16^{\text {th }}$ June, 2008),

'What is doubly sad is that some of the most battered banks are former building societies - those once prudent institutions woven into the fabric of British life.'

None of the de-mutualised institutions has survived as an independent institution, and two have failed and been taken into state ownership. Building societies have not received capital injections from the government and yet one of the arguments traditionally used against mutuality is that mutuals are more likely to face capital constraints because of their capital structure and governance model. On the other hand, plc banks (which in theory can always seek more capital from shareholders) have experienced serious capital shortages to the extent that government assistance has been needed on a large scale.

The distinction between banks and building societies has proven to be significant in the financial crisis. In 2008, and again in early 2009 , the government required the major banks to re-capitalise and inject around $£ 50$ billion of new equity capital of which $£ 37$ billion would be from the government (tax-payer) itself. Three of the five largest banks needed a massive ( $£ 37$ billion) capital injection from the state: they were partnationalised and credit risk was socialised. This meant that by early 2009 the state owned very substantial proportions of Royal Bank of Scotland, and the combined Lloyds/HBOS group. In effect, and for the first time in UK history, tax-payers became shareholders in banks and became exposed, therefore, to credit risk on a large scale. While many banks faced serious financial problems in the crisis and needed state injections of capital, only two medium-sized retail banks actually failed. They were both previous building societies that had demutualised partly in order to undertake business that was not feasible or allowed as a mutual (and to seek wholesale funding to a greater extent than allowed by the Building Societies Act), which proved to be the origin of their downfall.

As a result of the financial turmoil, building society profitability was significantly lower in 2008 than in previous years, and some building societies reported large losses for the first time in many years. It is also the case that some societies (Cheshire, Derbyshire,

\footnotetext{
9 For analyses and discussion of the 2008 credit crunch and subsequent global recession, see for example the various papers contained in the July 2009 special issue of the Cambridge Journal of Economics (Volume 33, Number 4, Oxford University Press), the July 2009 special issue of the Cambridge Journal of Regions, Economy and Society (Volume 2, Issue 2, Oxford University Press), and the series of podcasts on the global recession downloadable free of charge from the University of Oxford's iTunesU site, at www.ox.ac.uk
} 
Scarborough, Barnsley and Catholic) sought refuge through mergers. None of this is surprising given the enormity of the crisis in the banking and financial system, the serious recession, declines in property prices, and a generally weak housing market.

There are, however, major differences between the difficulties that have been faced by building societies and banks. Firstly, the problems of those building societies that have encountered a decline in performance have been focussed predominantly on the property market rather than funding models. Secondly, most building societies have not moved sharply away from their traditional model whereas, as described later, the magnitude of the problems faced by banks (and most especially some converted building societies) has been due largely to banks adopting new business models with a high dependence on securitisation, credit-risk shifting derivatives, and wholesale market funding. Overall, the building societies weathered the storm better than have the banks. There are three main reasons for this: firstly, regulation limited the extent to which building societies could diversify into the areas (e.g. derivatives trading) that proved to be a serious problem for many banks. Secondly, their mutual status meant that they generally had a lower risk appetite irrespective of regulation. Thirdly, both by regulation and choice, building societies limited their dependence on wholesale funding markets and securitisation.

However, some building societies did diversify away from their traditional business models and in particularly excessively into commercial property lending. To this extent, they developed a risk appetite inappropriate for a mutual. There may have been something of a failure of supervision as well as management. The most spectacular case was the Dunfermline which, at the end of March 2009, was in serious difficulty with a loss expected to be in the region of $£ 26$ million and with problems attached to its highrisk commercial loan book, some toxic assets, its IT infrastructure, and payments to be made to the Financial Services Compensation Scheme. In the absence of a merger partner, the government rejected a 'bail-out' option. Instead, the Society was broken up with Nationwide taking over the deposits and the solid part of the mortgage business with government and FSCS providing Nationwide with $£ 1.6$ billion to cover the excess of deposits over assets being absorbed - and the rump of the society (with the commercial property book, holdings of other toxic assets, and subordinated debt liabilities) put into administration.

There is a parallel between the experience of converted building societies and other banks and that of the Dunfermline. Just as banks got into difficulty because they stopped behaving like banks, equally the same is true of the Dunfermline which deviated from the traditional model of a mutual by diversifying into risk profiles unsuitable for a mutual. In their study of European savings banks for the EU Commission, Ayadi et al (2009) find that:

'The current financial crisis has affected the savings banks - and equally the cooperative banks - less than most other banks... This may also serve to strengthen the political support for both of these banking groups. That they are hardly at all directly affected by the crisis is due to the traditional business model that these banking groups have maintained over the years.' 


\subsection{Business models: mutuals v. converters}

The experience of converted building societies in the financial crisis has led to a reappraisal of the wisdom of mutual building societies converting to plc status. It has been argued, for instance, that:

'today the demutualisation dream lies in tatters. All of the building societies that did it have either gone or are shadows of their former selves... a perfectly viable industry which performed a vital public service in a reasonably well managed responsible fashion, has been completely destroyed'. (Warner, 2008).

Northern Rock converted to bank status in 1997. From the outset, it adopted a funding strategy which was increasingly based on wholesale money (including issuing mortgagebacked securities). It would not have been allowed to do this to the extent that it did had it remained a building society where regulation requires that the bulk of funding has to be from retail savings deposits. It was this strategy (securitisation and wholesale market funding) that eventually proved to be its downfall.

Although Northern Rock was not directly exposed to the US sub-prime mortgage market, it became caught up in the effects of the credit crunch because of its business model: securitisation as a central strategy, and reliance on short-term money market funding. More than 75 percent of Northern Rock's funding came from the wholesale markets, rather than retail deposits. It faced two related problems: it could not securitise and sell new mortgage assets and hence needed to keep assets on the balance sheet that it had intended to sell, and it faced a sharp rise in interest rates in the money market with the result that borrowing costs (even in the event that it could borrow at all) rose above the yield on its mortgage assets. Overall, because of its business model, it was particularly exposed to the risk that the markets would turn against mortgage backed securities and that liquidity in the commercial paper and money markets would become severely strained and might evaporate altogether.

Northern Rock's business strategy - involving a high and unusual dependency on securitisation and short-term wholesale market funding - exposed it to a low-probabilityhigh-impact risk. The drying up of liquidity in the London and international markets was a very low probability event (it is difficult to recall when it last occurred) and yet would have a large impact and be serious for any bank with a business model that relied heavily on securitisation and short-term funding through these markets.

It is instructive to consider a stylised review of the traditional model of the banking firm. Banks traditionally have information, risk analysis, and monitoring advantages which enable them to solve asymmetric information problems and hence mitigate adverse selection and moral hazard. In this standard model, banks accept deposits from one group of customers, and utilise their comparative advantages to transform deposits into loans. In this model, the bank accepts the credit (default) risk, holds the asset on its own balance sheet, monitors its borrowing customers, and holds appropriate levels of capital 
to cover unexpected risk. It also internally-insures its loans through the risk premia incorporated into the rate of interest on loans.

Furthermore, in this traditional model the bank is not able to shift credit risk to other agents because of its information advantages: a potential buyer of a loan from a bank might judge that, because of the bank's information advantage, the bank might select low-quality loans to pass on and, if it knew that it could pass on risk, it might be less careful in assessing the risk of new loans and would conduct less intensive monitoring of borrowers after loans have been made. For the same reason, the traditional view of the bank is that it is unable to externally insure its credit risks. In this traditional view of the bank, therefore, credit risk cannot be shifted or insured, there is no liquidity to bank loans, and banks are locked into their loan portfolios.

Many aspects of this traditional model came to be questioned. In the securitisation model, the process of securitisation (including via Collateralised Debt Obligations) means that the bank is able to sell loans (which the traditional model denies) and hence the bank does not hold the loan asset on its own balance sheet, does not absorb the credit risk, and hence does not need to hold as much capital against the credit risk. However, this depends upon precisely how the securitisation is conducted and most especially whether the Special Purpose Vehicle is truly bankruptcy-remote from the bank and vice versa, and whether - apart from contractual liability - the bank is in practice committed to the SPV because of reputational risk.

Although there are many contributory factors to the financial crisis, at the centre was a shift by banks away from the traditional model of banking towards securitisation, the use of Shadow Banks, and substantial use of credit derivatives that purport to shift credit risk. In effect, banks stopped behaving like banks. As argued by Llewellyn (2009a and $2009 \mathrm{~b}$ ), this change in business model can be regarded as the ultimate cause of the crisis. ${ }^{10}$

\subsection{Remutualisations?}

The objective of the government in the case of Northern Rock (and with other banks that have received government support) is that the net cost to the tax-payer should be minimised. The question arises, therefore, as to why the government should support a remutualisation if the logistics meant that the capital provided by the taxpayer might not be fully repaid? Quite aside from the need to repay loans, the company reported losses over the first half of 2009 of $£ 725 \mathrm{~m} .^{11}$

10 The proposal from Kay (2009) and others to split the risk taking business of investment banking from traditional 'narrow' banking services is one of the ways in which this problem can be tackled - so that 'the utility can be readily separated from the casino' (Kay, 2009, p. 26). Such a move would be entirely synergistic with a strengthening of the mutual sector.

11 And at the same time reported that the proportion of its mortgages which were more than three months in arrears had risen to 3.9 per cent, with almost forty per cent of mortgage borrowers being in negative equity. 
Given the systemic (externality) advantage in enhancing the mutual sector (in effect, reinstating the status quo ante before Northern Rock was de-mutualised), the tax-payer has a legitimate interest in the project. The systemic and competitive benefits of remutualisation (even if it meant some form of indirect tax-payer contribution) would outweigh any cash benefit to be derived from a quick sale of the Government's capital holding in Northern Rock.

The case for remutualising Northern Rock can be made on the basis of the intrinsic merits of the mutual model, the systemic advantage of having a mixed system with a critical mass of mutuals along with other bank models, and the enhanced competition to which a remutualised Northern Rock could contribute. A study of European savings banks undertaken for the EU Commission by the Centre for European Policy Studies concludes that:

'the current crisis has made it even more evident than it may always have been how valuable it is to promote pluralist markets in Europe and for this purpose to protect and support all types of ownership structures ... The investigation of the role of savings banks in this study showed a positive value of their presence in terms of financial, economic and social welfare in the countries where they operate. Moreover, in the context of the current financial crisis and the likely regulatory responses to manage the crisis and avoid the emergence of the next crisis, the dual bottom line nature of banks such as savings banks may prove to be an opportunity to withstand the crisis through their specialisation in gathering deposits or selling their reputation as solid contributors to financial stability and economic growth.' (Ayadi et al., 2009).

And as the Bank of England's Executive Director for Financial Stability recently argued:

'...I am happy to say that the death of the mutual building society are greatly exaggerated. Indeed, mutuality may do a better job of aligning stakeholder incentives than some alternative forms of corporate governance. It is a depressing but telling fact that, of the demutualised former UK building societies, none is today in independent ownership.

'Thift, mutuality and relationship-building have long underpinned banking in Yorkshire. These principles went missing in the run-up to the current crisis. The costs of that vanishing act are now all too apparent. In rebuilding the financial system, to create one which is both stable and better able to meet the needs of the real economy, these principles need to be rediscovered. They represent a tried and tested - indeed, trusted - roadmap for the period ahead.'

(Haldane, 2009b, page 15)

We now consider the political, financial, legal and governance issues that would need to be tackled in pursuing a remutualisation strategy. 


\section{The politics of remutualisation}

The UK Government has been proactive in response to the global banking crisis by providing funding and capital support. In its own words:

'The Government's actions have had three core objectives:

- to support stability and restore confidence in the financial system;

- to protect retail depositors' money; and

- to safeguard the interests of taxpayers.

'Northern Rock was taken into temporary public ownership in February 2008 using the Banking (Special Provisions) Act 2008, after it had experienced severe funding problems and no buyer could be found to stabilise the bank in a way that protected the interests of taxpayers;

'The global financial crisis has inevitably led to significant disruption to the operation of financial services. This disruption has the potential to cause firms to become disconnected from their customers; particularly as ordinary individuals and small businesses, who rely on their banks for the provision of essential dayto-day services, have lost trust in these firms.'

Reforming Financial Markets, HM Treasury, July 2009

Across the world, policy makers are searching for ways to prevent banks from repeating the behaviour which led to the high risk strategies that ultimately led to their collapse. In April 2009, G20 leaders pledged to apply tough new policies on banker compensation. Since then, a range of ideas have been floated that have focussed on the remuneration packages that incentivised risk taking. It is widely accepted that the bonus culture which rewarded short term risk taking in banks - was a major contributor to the banking crisis. There has been public disquiet that leading banks, which have been seen as a major cause of the financial crisis, have been receiving taxpayer funds but are not prepared to change their traditional culture of awarding big bonuses. So far, a number of countries have taken individual action. France's banking federation has agreed to bring in a new system of performance-related pay, following controversy over the high levels of bonuses paid to traders, announcing that there would be penalties for those who lost money as well as rewards for success. The US House of Representatives voted to stop banks paying bonuses that promote 'excessive risk-taking'. The vote came after a report by the office of New York Attorney Andrew Cuomo suggested that Wall Street banks that were bailed out by the government gave executives bonuses regardless of performance.

Here in the UK, the main tool used by the FSA so far to eliminate excessively risky activity has been a demand for higher capital and liquidity in financial institutions. This has certainly made them 'safer' institutions, but has also had the effect of restricting lending to the market generally as funds are hoarded in banks instead of circulating throughout the market, and banks have to rebuild their capital in part by constraining or even shrinking their balance sheets. Announcements in August 2009 suggested that 
bankers' pay deals are to be linked more closely with the long-term profitability of banks under new rules from the Financial Services Authority. The FSA says that bonuses should not be guaranteed for more than a year, and that senior employees should have their bonuses spread over three years.

Yet these changes, and others expected following the G20 in Pittsburgh in autumn 2009, have yet to satisfy the debate. The early stages of recovery in banking performance have led to fears that there is a return to 'business as usual' in the banking sector.

Further radical ideas are being floated that include the suggestion that new global taxes may be necessary to curb excessive profits and pay in the financial sector. Such taxes would perhaps be levied on transactions to reduce profits and the ability to pay bonuses. Popular anger on the issue of bank bonuses has also led to calls for a 'High Pay Commission' which would seek to 'measure the claims of top earners that their rewards are justified and necessary, even if they offend natural justice and our sense of fairness' (Vince Cable, Guardian, August 2009).

\subsection{The structural problem}

These ideas are designed to change the behaviour of the capital driven and inherently short-termist global banking system. They focus on what has been seen as the riskiest part of the banking industry and aim to rein in the most extreme behaviours. Politicians will be keen to be seen to take action to deal with these problems, yet will be aware that they cannot dictate how the markets will ultimately behave - the culture of financial institutions is part of their DNA - and this means that they will behave as their corporate make-up dictates. Policy interventions are therefore limited to attempts at introducing corrections to expected behaviour, which is inherent in that system. The only way to be certain of changing the behaviours is to change the system.

Where the Government has an ownership stake in banking institutions it should act to create a situation that positively influences behaviour towards its stated objectives. The best way that the UK could achieve this is to place structural inhibitors on the behaviour of its disposals. By changing the purpose for which it does business, the Government could establish Northern Rock as a new mutual that will have an inherently more favourable culture and less risky behaviour in its future business. The Government has already recognised the logic of much of this, stating in its White Paper, Reforming Financial Markets:

'The Government proposes four important sets of actions to reinvigorate competition in the banking sector:

- given the importance of regulation in creating barriers to entry, it is essential to ensure that market access is firmly embedded into decisions about financial rule-making, including through the work of the OFT, the FSA and the EU, and that these and other institutions work together closely;

- supporting competition and choice through diversity, most importantly through maintaining a strong mutually-owned financial sector, by: 
o ensuring that its regulatory and legislative framework is modernised;

o supporting better governance; and

o considering the sector's needs for capital and funding;

- Government action where markets cannot provide solutions, such as supporting innovation - through the Innovation Fund - and social investment; and

- ensuring an orderly exit from the various interventions, in the UK and internationally, making clear that the Government intends to sell the equity stakes that it has invested in UK banks.'

Remutualisation would be popular because the Government would be seen to be acting in the interests of future stability in the economy. It would contrast starkly with fears that a privatised Northern Rock would be released from the Government, at a knock-down price, merely to repeat its previous errors. UK Financial Investments (UKFI) must, therefore, consider the remutualisation option seriously. ${ }^{12}$

\subsection{An exit strategy - disposal as soon as appropriate}

'The Government will dispose of Northern Rock as soon as appropriate in a manner that will promote competition for retail services, secures the best possible return to taxpayers and ensures that Northern Rock will continue to increase its lending to homeowners.'

Reforming Financial Markets, HM Treasury, July 2009

In its half yearly statement to 30 June 2009 , Northern Rock reported that:

i. Plans for legal and capital restructure are progressing well, with completion expected before the end of 2009, subject to European Commission (EC) and Financial Services Authority (FSA) approval.

ii. The intention is to split Northern Rock into two separate entities, BankCo and AssetCo.

iii. Northern Rock continues to support the Government in its revised application for State aid.

Gary Hoffman, Chief Executive of Northern Rock commented:

'The current environment continues to be challenging, however, against this backdrop Northern Rock is making progress against its revised plan and has delivered results in line with expectations. We anticipate receiving State aid approval in the autumn and the legal and capital restructuring of the Company to be completed by the end of the year. This ultimately prepares for a return to the private sector.'

Clearly, once the business is restructured a disposal can go ahead. The policy decision of how to dispose of the business at that point will then depend on how the options will

12 UK Financial Investments Limited (UKFI) is wholly owned by the Government. 
deliver against the stated policy objectives of HM Treasury. We can probably discount the possibility of the business being privatised in a traditional flotation: although there has been speculation that a floatation of UKFI holdings is an option that might be considered by a Conservative administration, it is difficult to see how sufficient confidence will be engendered in a public sale of shares in what is effectively a damaged brand. Our comparison is therefore limited to the two realistic options for the Government:

i. a trade sale of BankCo to another corporate entity that wishes to extend its operations, or

ii. the transfer of the business to a new mutual organisation.

The table below tests these two options against the stated HM Treasury policy objectives.

\begin{tabular}{|c|c|c|}
\hline $\begin{array}{l}\text { HM Treasury Policy } \\
\text { Objective }\end{array}$ & Trade sale of Northern Rock & $\begin{array}{l}\text { Transfer of Northern Rock to a } \\
\text { mutual structure }\end{array}$ \\
\hline $\begin{array}{l}\text { Promote competition } \\
\text { for retail services }\end{array}$ & $\begin{array}{l}\text { If the business is sold to a current } \\
\text { competitor, then this will limit } \\
\text { competition. This is effectively what } \\
\text { happened as a result of the } \\
\text { demutualisation of Building Societies, } \\
\text { which all (apart from Northern Rock) } \\
\text { were absorbed into competing banking } \\
\text { businesses, with the net result of less } \\
\text { choice for consumers and a more } \\
\text { homogenised market. Ultimately, this } \\
\text { has been recognised as a factor that } \\
\text { contributed to the concentration of risk. }\end{array}$ & $\begin{array}{l}\text { The maintenance of a reformed } \\
\text { Northern Rock as a separate corporate } \\
\text { entity is good for competition. As a } \\
\text { mutual entity that is committed to its } \\
\text { core business, a reformed Northern } \\
\text { Rock Mutual will help the } \\
\text { Government to meet its policy } \\
\text { objective. Indeed, HM Treasury has } \\
\text { already committed itself to supporting } \\
\text { diversity through the maintenance of a } \\
\text { strong mutually owned financial } \\
\text { sector. }\end{array}$ \\
\hline $\begin{array}{l}\text { Secures the best } \\
\text { possible return }\end{array}$ & $\begin{array}{l}\text { The trade sale value of Northern Rock in } \\
\text { the short term is likely to be suppressed } \\
\text { by historically low share prices. Indeed, } \\
\text { it is hard to see how a rapid sale might } \\
\text { maximise the return for the UK taxpayer. } \\
\text { It will carry the huge political risk of } \\
\text { quickly appearing to have been a poor } \\
\text { deal as markets continue to recover. }\end{array}$ & $\begin{array}{l}\text { Once restructured, the trading part of } \\
\text { Northern Rock will be a healthy } \\
\text { business - it would need to be to have } \\
\text { a sale value. This will permit the } \\
\text { Treasury, over time, to realise the } \\
\text { value of the shareholding, possibly } \\
\text { via a PPDS-type capital structure. }\end{array}$ \\
\hline $\begin{array}{l}\text { Ensures that Northern } \\
\text { Rock will continue to } \\
\text { increase its lending to } \\
\text { homeowners }\end{array}$ & $\begin{array}{l}\text { Once privatised, and owned } \\
\text { independently, Government will have no } \\
\text { control over the future of Northern Rock. } \\
\text { Its owners will behave as profit- } \\
\text { maximising investors and will make } \\
\text { their decisions accordingly. }\end{array}$ & $\begin{array}{l}\text { A new mutual Northern Rock could } \\
\text { be constituted with the express } \\
\text { intention of meeting this policy } \\
\text { objective, in the public interest. If it } \\
\text { took the form of a building society, } \\
\text { this would be automatic, given their } \\
\text { statutory principal purpose. }\end{array}$ \\
\hline
\end{tabular}




\subsection{The EU}

In 2007, the EU Commission published a report on European retail banking (2007/2201/INI). The European Parliament subsequently issued a Resolution on $5^{\text {th }}$ June 2008 which included the following statement:

'the diversity of legal models and business objectives of the financial entities in the retail banking sector (banks, savings banks, co-operatives, etc) is a fundamental asset to the EU's economy which enriches the sector, corresponds to the pluralist structure of the market and helps to increase competition in the internal market.' (European Parliament Resolution, 5th June, 2008)

A subsequent report prepared for the EU Commission (Ayadi, et al, 2009) argues as follows: 'legal, political and risk-related considerations serve to highlight the need for a European banking model based on diversity...'. In their study of savings banks in Europe, Ayadi et al (2009) find evidence that 'in those countries in Europe which still have active savings bank systems, [social] exclusion is less of a problem than in others that do not'.

\subsection{Diversity of financial service providers}

As far as the UK is concerned, the banking crisis has highlighted the importance to the UK economy of retaining diverse models of financial service providers. And while mutuals were affected by the recession, they were not themselves responsible for causing the recession, as was the case with the private banking sector. HM Treasury recognised this in the Budget Report and has taken action to assist building societies to meet tougher capital requirements. One of the key conclusions of the current Report is that given the barriers to entry to setting up a new mutual of any size in the deposit-taking sphere, it makes sense to explore the remutualising of a mature ex-mutual business, as well as conserving existing mutuals.

While the 2009 Budget report included a section supportive of mutuals, this has yet to be backed up with any tangible policies or actions from Government to support mutuals and to promote the development of a stronger mutual sector in order to create a more balanced and sustainable financial services sector for the UK economy - one which would service and support the real economy rather than gamble with it for the short-term financial benefit of private banks and their managers.

There is a danger that the UK Government might be tempted by a short-term 'dash for cash', selling the failed financial institutions to the highest bidder. This would be a serious mistake likely to cost the UK economy in the long term. Firstly, paying off the public sector debt that was incurred as a result of the speculative behaviour of private sector banks, which caused the global credit crunch and subsequent worldwide recession, cannot happen overnight. So, too, the timescale over which the performance of the oncefailed financial institutions will need to be judged, and over which they could be expected 
to generate a return to the taxpayer, should not be too short. The remutualisation option will provide less cash up-front in the short term, but will create more durable and sustainable businesses which will therefore be in a position not only to make repayments over time, but also to contribute positively to the UK economy in terms of enhanced competition in the financial system, services provided, jobs created, and tax revenues generated for the Treasury.

Government needs to take account not only of cash returned to the taxpayer, but also the risk that the tax payer will be subjected to a similar - or even quite novel and dissimilar financial crisis in the future, once again subjecting the taxpayer to the financial costs of bailing out the private sector banks and the economic costs of any concomitant recession. The Government needs to secure both a financial return and an acceptably low level of financial and economic risk for the taxpayer. If there is a trade-off, then the long-run benefits of financial sustainability and reduced risk need to be given proper weighting.

In addition to remutualised enterprises being able to make a long-term return to Government, and contribute to a more resilient and less risky financial sector, a stronger mutual sector, reinforced by newly remutualised businesses, would also be better placed than would private banks to deliver on the broader social agenda.

The new owners could be all who register an interest in membership of a bank run for their benefit; it could be a co-operative, a building society, or a new type of mutual bank. But what would prevent members in the future demutualising - cashing in the value that had been built up, sacrificing the future benefits that the mutual form would deliver, and once again subjecting the economy to a financial sector driven by the short-term financial interests of shareholders of and managers in private banks? The answer is that this would need to be prevented by having an asset-lock, so the members are only stewards of the company and its assets, to hand on to future generations. (Most building societies have incorporated similar 'defence mechanisms' in their conditions of membership by requiring new members opening an account to assign - for at least five years - any future demutualisation windfalls to which they might be entitled, to charity.)

\subsection{New mutuals}

The politics of what is being proposed is not therefore simply to secure a more competitive and sustainable financial services sector for the UK over the long-term, but also to strengthen the mutual model at the same time. More secure mutuals will minimise the risks for UK taxpayers of the financial services sector becoming once more dominated by private banks intent on short-term financial returns whatever the risk to the wider economy and society. This is not therefore a return to the (pre-1990s) past welcome though that might appear given what the demutualisation and light-touch regulation of the 1990 s delivered. It is a proposal to create a new and more secure mutual form, which in turn can underpin a more durable and sustainable financial services sector.

A radical but arguably politically attractive option would be to offer every taxpayer a stake in (say) Northern Rock, through the government, to create a 'peoples bank' directly 
owned by each taxpayer. The bank would over an agreed period of time 'pay back' outstanding debt but the equity value would effectively be gifted to the beneficial owners - the tax payers. The governance of such a new creation would require a new model, and this could itself be a positive opportunity to turn what has been a costly failure of the old models to our advantage, by developing new and more durable structures. In other words, any remutualisation need not imply precisely the same model as currently exists even though the basic philosophy of mutuality is retained: just as we argue the case for 'bio-diversity' within the financial sector generally, there can also be different modalities within the basic mutual model. 


\section{$5 \quad$ Financial issues}

For any of the failed financial institutions to be transferred out of public ownership would most likely require the 'good bank' - to be transferred - to be split from the 'bad bank' that would need to be managed out by specialists for UKFI, minimising taxpayer losses. The good bank would hold deposits and start to grow again its mortgage lending. Were the failed financial institutions to be remutualised, they could also provide the infrastructure for central services for smaller mutuals - lowering their costs and helping them to compete, thus further strengthening the resilience and stability of the country's financial services sector.

As the Government's senior debt could be repaid over time under any ownership scenario, the main financial issue is realising the equity value of Northern Rock for the taxpayer. It is unclear how much this value is, but an early trade sale, at today's prices and in a rising market, would almost certainly prove a poor bargain. Given that remutualisation would strengthen competition and create a more diversified financial sector, it could be expected to generate an advantage to the taxpayer over the long run in excess of the immediate benefit of a capital repayment in the short run.

\subsection{New financial instruments}

The Financial Services Authority announced earlier in 2009 a new instrument for the building society sector - profit participating deferred shares or PPDS - allowing capital to be provided in a way that carries modest servicing costs to begin with but can deliver a fair overall return in the long term. This could overcome one of the fundamental problems of either setting up a new mutual or mutualising an existing business: how to raise the necessary capital when to begin with the business cannot afford to pay a high return on the investment.

While a capital instrument of the PPDS type is unlikely to attract new investors, it may help restructure some of the existing capital, and a more attractive version of PPDS could be issued to UKFI as consideration for its equity, and either held for income, redeemed, or sold in due course into the market - which may be much quicker than just waiting for retained profits to be generated in sufficient quantity. Such a capital instrument could help other mutual financial institutions, thus strengthening the sector.

Thus, to the extent that it is necessary to raise substantial amounts of new capital, a mechanism and appropriate financial instruments are needed which do not undermine or conflict with the commitment to the public purpose. Individual savers and members could also provide some risk capital, though this needs to be handled carefully. Institutional funds, could be raised either as PPDS or as conventional permanent interest bearing shares (PIBS) or as varieties of hybrid capital or subordinated debt. 


\subsection{Locking in diversity}

The key point, though, is that the equity endowment with which a remutualised institution would start off, would need to be held in a way that protected the wider public interest, and not as the exclusive property of the members (or customers) of the mutual. Hence the need for the assets to be locked-in for the purpose intended. That purpose would be to create a strong mutual underpinning to the UK financial services sector, create a diverse ownership and behavioural structure, promote competition, diversify the economy geographically as well as by ownership and governance structures, reduce risk of financial crisis and economic recession, and promote community benefit.

It has to be accepted that this low-risk model will be a relatively low-return business, especially if the remutualised businesses are required to make future payments to the taxpayer. Indeed, it has been suggested that this is precisely what we need to aim for, to create the situation where 'Banking becomes a low risk, low return business'.

That was certainly the view of John Maynard Keynes on the appropriate role of financial capital within the economy. The shift in economic thinking and policy that is required is an appreciation that if the investment decisions of an economy are left to the vagaries of speculative financial markets, then the job is likely to be ill-done. The financial sector needs to be the servant rather than the master. The great breakthrough coming out of the 2009 global recession - the first global recession since the 1930s - would be if policy makers learned the lessons of Keynes's analysis, namely that financial markets at times behave irrationally, with investors driven by herd effects and 'animal spirits'. We need to damp down and rein in these volatile drivers, and thus make investment more durable and sustainable. That is always going to be a hugely difficult task, of historic importance. It means going against the grain of private banking and the behaviour of markets. It is hard to see how the global economy can make that breakthrough to a more sustainable economic paradigm - other than by remutualising failed financial institutions, strengthening the mutual sector, and creating a diversity of ownership and governance models so not all managers are incentivised by the same drivers, nor following the same herds. The economic and hence financial returns from making this historic choice are potentially enormously beneficial. But it requires a commitment from Government to the long view. 


\section{$6 \quad$ Legal and governance issues}

The aim of any ownership and governance structure is to provide a stable framework to hold a business for the foreseeable future. If such a structure is to be effective, the following elements are needed:

i. Clarity of corporate purpose, and in particular whether the entity is trading for the private benefit of investors (traditional investor-ownership), or the collective benefit of members (which is the traditional mutual or co-operative approach), or for the wider public benefit unconnected with membership

ii. An ownership structure which captures the self-interest of the owners in such a way that they are predisposed to use their ownership rights to enforce the corporate purpose (i.e. they are driven by self-interest) - thus, the rights of investor-shareholders and the legal duties on directors to optimise shareholder value in the investor-ownership model, with customer-membership and the traditional mechanisms of information, voice and representation in the mutual model

iii. A professional governing body

a. whose competence is assured (as far as it ever can be) because they are appointed by merit

b. which includes appointed independent professional non-executives, who can properly scrutinise the executives and management

iv. A mechanism which locates the governing body within a structure of accountability to the owners or their representatives.

For robust and healthy governance, it is important that all parts of the ownership and governance structure work well, especially at grass-roots level: the owners are the ultimate driver of the organisation, the mechanism for approving or rejecting strategic or structural change, and the ultimate restraint on the taking of inappropriate risks. It was arguably the failure of this element which enabled demutualisations to occur. They were driven by over-powerful management, not the members, and the members were too weak and disorganised (and attracted by the short-term gains) to do anything about it. If there is a future in the mutual provision of financial services, which we clearly believe that there is, then we should be striving for a more robust model:

i. which strives to address previous structural weaknesses;

ii. which openly promotes a mutual funding and business model as its fundamental selling message;

iii. self-evidently demonstrates how mutual ownership drives the business to be successful; and

iv. attracts and retains customers on that basis. 


\subsection{Corporate purpose}

To have a credible long term commitment to mutual or co-operative principles, or to the public benefit, two things are needed.

First, safeguards are needed against members in the future demutualising to cash in on the value accumulated by previous generations. In the short term this can be via the sort of trust device or other types of predator protection currently in use. Longer term it might be through legislation to introduce an asset lock into the existing building society model, or by using an alternative legal form which already permits an asset lock such as the community benefit society model.

Second, if new financial instruments for the mutual sector along the lines of the profit participating deferred share are to be developed, these would need to be carefully regulated. It is legitimate to pay compensation to providers of capital for the use of their capital, but not to allow funders to extract a 'share of profits' if this imposes upon the entity an obligation to 'generate profits' for this purpose.

\subsection{Ownership}

If the entity is committed to a collective purpose, then members are 'owners' of the organisation in the sense that:

i. the members (and nobody else) collectively own it;

ii. members are entitled to their capital (on whatever terms it has been subscribed);

iii. but members have no entitlement to a share of the underlying value of the business: they are holding any excess capital value on trust for the future benefit of the entity and its members, to continue to deliver its principal purpose ('disinterested' ownership);

iv. as owners, members have a series of rights, which can be grouped under the headings information, voice and representation; and

v. this is the route by which they own and control the entity.

The development of a strong and growing mutual financial services sector depends upon the development of interest and demand from potential members. Any 'top-down' initiative by government to reinvigorate the sector by remutualising financial institutions must be accompanied by a properly resourced initiative to stimulate and nurture member participation. It is vital that 'mutuality' is seen not just as a different form of ownership, but a different business model which adds value to the business per se, and which therefore attracts popular consumer support. 


\subsection{An asset lock}

Legally, a remutualised financial institution could be either a building society or another type of financial mutual. Crucially, an asset lock would ensure members benefitted only from their ongoing financial relationship with the business. They would have no right to the underlying assets as these would, in effect, be held 'in trust' for future members or for the wider public benefit. This asset lock could be achieved through charitable assignment practices common in other mutuals. A more secure structure for the long-term future would be for new legislation, fit for purpose, which would require only a simple legislative change. But remutualisations could, in the meantime, proceed using the existing charitable assignment practice.

\subsection{Management and links to membership}

There are several options for how membership could be offered; it could be held by existing and new customers of the previously failed financial institution (for example Northern Rock), and would accrue benefits as long as the members trade with the mutual. Crucially, it would be clear up front that it did not confer an individual proprietary stake in the business: and the underlying assets could not be demutualised.

There are regulatory requirements for assuring board competence for building societies. Independent professional non-executive directors are part of that, and clearly must continue to be. Many would argue that a unitary board remains the preferred option if member participation is to be encouraged and optimised. However, for others, it may be more appropriate to explore a two-tier structure, providing wide opportunity for member participation in formulating strategy, and creating a context for interaction between the representative part of the organisation and the executive part.

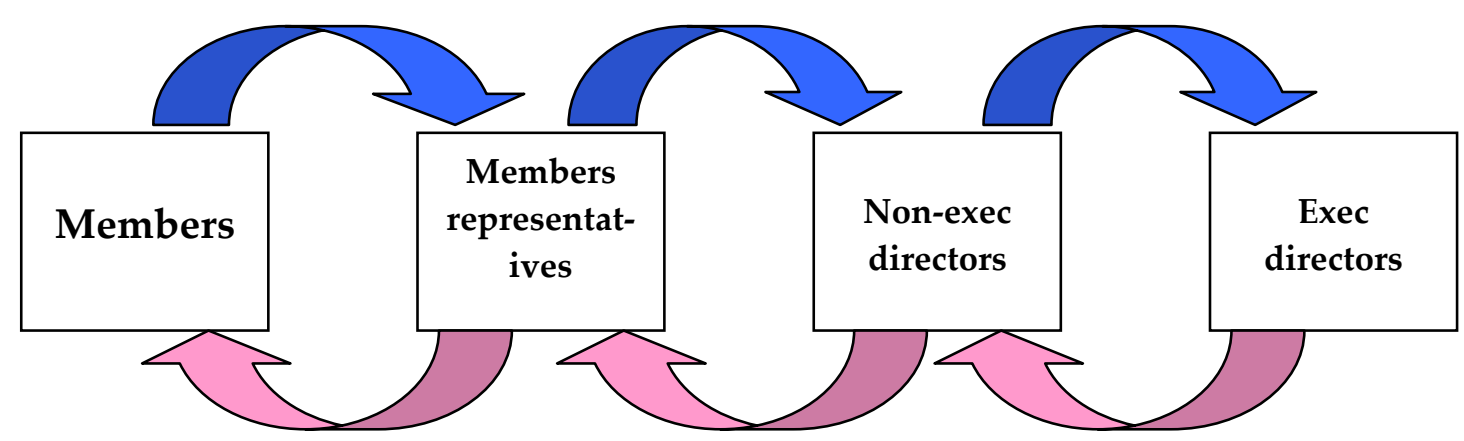

People understand the concept of ownership. With a government owned asset the electorate, tax-payers or citizens have collective ownership. In traditional mutual organisations, members generally understood that they owned it collectively - but during the 1990s many commentators peddled the misconceived idea that a member owned an individual stake, hence the rush to demutualise. But with an asset-locked arrangement 
the idea of an ownership share is very clearly a share of a common fund. What the government would be doing would be taking the existing publicly-held equity and putting that equity in a trust and allowing people a vote in that trust - it would in a sense be inventing something new. There would be a political determination plus an improved model that would both contribute to the outcome being improved on what has gone before. The financial sector would be stronger because of being more competitive, more diversified, and because of having a mutual core that does not suffer from the same shortterm herd effects and other detrimental incentives and outcomes that plague the shareholder-owned financial institutions. But in addition, the mutual model itself would be stronger. An improved mutual sector underpinning a more sustainable financial sector would be the outcome. 
The EU Commission recently commissioned a major study on European savings banks, conducted by the authoritative Centre for European Policy Studies (CEPS). ${ }^{13}$ The analysis - both theoretical and empirical - considered savings banks (along with other not-mainly-for-profit banking institutions) to be 'dual bottom line' institutions in that they have a broader definition of the bottom line than the norm with traditional Shareholder Value banks. The study finds that savings banks enhance competition in the financial sector, enhance stability characteristics, contribute to alleviating social exclusion and, because of their local focus, contribute to regional development. In particular, a strong case is made in favour of diversity in the financial system with contrasting business models competing with each other. This need for a more diverse financial system applies equally to the UK, and a historic opportunity presents itself in the form of failed financial institutions having been taken over by Government, which is now able to decide what form these organisations should take when they leave government ownership. Specifically, should they return to the private banking sector, reinforcing the sector that created such huge financial problems and economic costs, or should they be remutualised, helping to rebalance the financial sector along more robust and sustainable lines, promoting diversity of structure, risk taking and corporate behaviour, and enhancing competition?

\subsection{UKFI and Northern Rock}

HM Treasury/UKFI will be considering how to dispose of Northern Rock. It could be sold in a trade sale, floated as an independent entity, or more imaginatively, converted to a mutual. Northern Rock, an ex-mutual, remains a relatively straightforward and mature savings and mortgage business - at least once the balance sheet has shrunk a bit and any toxic assets neutralised, which are issues currently being addressed. As such, it is particularly suitable for returning to mutual ownership.

\subsection{A vision for a robust financial sector}

It has been argued in this Report that the UK economy would benefit significantly from transferring Northern Rock into a new mutual society. This would:

i. Create a stable financial services provider, constrained from repeating its previous mistakes.

ii. Be achieved at relatively little net cost to HM Treasury, and may even give a superior return in the long run - certainly in terms of economic sustainability.

iii. Counter the further concentration and loss of competition likely to result from a trade sale.

iv. Avoid the political risk of selling the holding into a depressed market, and losing value for the taxpayer.

v. Make a strong statement that the Government intends to support responsible financial institutions.

$13 \quad$ Ayadi et al. (2009). 
vi. Promote competition in the financial system.

vii. Support diversity in financial institutions.

viii. Secure the future value of the business for the benefit of its customers, but also, by enhancing competition and strengthening diversity, also for the public benefit more widely.

The May 2009 Report from the Treasury Select Committee concluded that:

To date, building societies have generally been shown to have operated a safer business model. Certain features of the building society model, including the comparatively low reliance on wholesale funding and the focus on the protection of members rather then the service of shareholders, have left building societies better equipped to defend against the shockwaves of the current crisis. We heard evidence that establishing new building societies was now harder than it was when the Ecology Building Society was started in 1981. The Government should examine, with the sector, whether any legislative or regulatory changes are required to facilitate building society start-ups and remutualisation.

(Treasury Select Committee, 2009, Paragraph 63)

The Government should respond to this call by remutualising one or more of the failed financial institutions that are currently in public ownership. The overarching objective of UK Financial Investments Limited is to protect and create value for the taxpayer as shareholder with due regard to the maintenance of financial stability and to act in a way that promotes competition: these objective would be best secured through the remutualisations of the failed financial institutions. Creating strong and sustainable entrants to the financial sector in the form of new mutuals would be the surest way of delivering the objectives set out by the Chancellor:

'A stong, stable financial system ... depends on effective competition, essential to make sure consumers have choice and no one faces excessive fees and charges. I have already committed the government to encouraging new entrants to the banking market as we reduce and ultimately remove government support from the sector.' Alastair Darling, The Observer, September $13^{\text {th }} 2009$, page 28 


\subsection{A route map for establishing Northern Rock as a mutual}

The Government's ambitions to relinquish its ownership of Northern Rock while boosting competition in the financial services sector can best be achieved through a remutualisation. This would require the following ten steps:

i. HM Treasury states that it wishes to consider fully all options for the future of Northern Rock;

ii. UKFI conducts a full feasibility study of the potential for a Northern Rock mutual, based on the ideas outlined in this Report;

iii. If acceptable, HM Treasury announces its intention to establish Northern Rock Mutual, and the nature of the new entity and the terms of the transaction are made public;

iv. HM Treasury agrees an appropriate schedule for the repayment or refinancing of the Government's senior debt by the new mutual;

v. HM Treasury settles the basis and outline timetable on which the value of UKFI's current equity holding is to be realised, and the desired capital structure of the new mutual;

vi. Northern Rock Mutual is registered as a new corporate entity, asset locked for public benefit;

vii. An independent, suitably qualified Chairman is recruited;

viii. A new Board of suitably qualified Directors is recruited;

ix. All existing customers of Northern Rock become members of the new mutual; and

x. Northern Rock 'BankCo' is transferred to the new mutual, possibly in consideration of the issue to the Government of a new type of mutual capital instrument (cf PPDS).

This represents a clear and achievable route map towards a more competitive and sustainable financial services sector. 


\section{Appendix: The demutualisations of the 1990s}

This Appendix reports briefly on the nature and causes of the demutualisation trend of the 1990s. In 1986 building societies were given the option of abandoning their mutual status and converting to proprietary banks and ten of the previous largest twelve societies did so. The conversion of some of the largest building societies represented a major structural change in the financial system, shifting the balance between mutuals and banks in the retail savings and mortgage markets.

The conversion movement was, in part, a reflection of the free-market consensus that favoured the shareholder-value (SHV) model in banking where the almost exclusive objective of bank mangers is to maximise shareholder value and often based on a fairly short time horizon. Non-SHV institutions (such as mutuals) were criticised for being an exception to this rule, for being relatively inefficient, for not being subject to the discipline of the capital market and the market in corporate control, and for having weak corporate governance arrangements. Above all, it was alleged that their objectives were not clear because of the absence of a single focus. However, many of these oft-repeated criticisms can be, and have been, challenged in an extensive research literature.

The economic rationale for the demand for conversion could be regarded as a demand by existing members of societies to unlock their supposed entitlement to locked value (see Drake and Llewellyn, 2001). In practice, however, it became opportunistic in that the motive was to secure windfall gains (sometimes amounting to several thousand pounds for individual members) which could also be reaped by new members who made nominal deposits at building societies with the sole purpose of pressing for conversion and expropriating a share of the reserves. However, the major declared motives for conversion were different:

\section{i. $\quad$ To secure greater access to capital}

With the exception of the issuance of PIBS or subordinated debt, the only source of capital for building societies is the surplus earned on its operations.

\section{ii. To secure a stronger position to participate in structural change in the financial system}

Some converted building societies stated in their conversion documents that one motive for conversion was to be able to take a more pro-active part in the consolidation and re-structuring of the financial sector. ${ }^{14}$

\section{iii. To gain more flexibility with respect to lending, and funding}

Building societies face limits on the extent of their wholesale funding (which cannot exceed a maximum of 50 per cent) and on diversification away from residential mortgages (which must represent a minimum of 75 per cent of their lending).

14 Principally because as plc's they would in due course be able to offer listed shares as consideration in any mergers or takeovers. 


\section{iv. To diversify into areas where the nature of the risk is judged to be inappropriate for a mutual, such as financial trading}

Because mutuals cannot readily increase their capital by fresh injections, they tend to adopt a lower risk profile. Thus, if a mutual planned to diversify into high-risk business, it would be appropriate for it to convert. For building societies this was also mandated by legislation through certain prohibitions on riskier forms of financial trading.

These were the stated arguments the management of building societies put to Members as reasons for conversion and seeking their votes for conversion. These demutualisations were facilitated by badly drafted conversion provisions inserted late into the Building Societies Act 1986 - and then a failure to do anything about the fact that the legislation had been badly drafted and did not deliver the intended outcome: this enabled a 'get rich quick' option at board level and immediate cash bribes to current members. (For a more detailed discussion of the reasons for conversion see Drake and Llewellyn, 2001.) In any case, the consensus that underlay much of the above rationale has come under challenge as a result of the global financial crisis particularly with respect to short-termist 'shareholder value' strategies and the assumption that efficient markets based on shareholder value models are self-correcting.

The experience of those building societies that demutualised

The conversions that occurred in the 1990s amounted to a very substantial demutualisation of the building society sector as, while it was only ten of the 89 Societies that existed in 1992 that demutualised, because they were amongst the largest, they represented around 70 per cent of the sector's assets. By the end of 2008 all the converted building societies had lost their independent status either because they were purchased by other banks (for example Abbey National and Alliance \& Leicester were purchased by Bank Santander) or because they failed and were taken into public ownership (Northern Rock and Bradford \& Bingley).

The subsequent history of the demutualised building societies indicates that problems emerged on both sides of the balance sheet. Thus, Abbey National (the first of the societies to convert) encountered problems because of its diversification on the assets side of the balance sheet, particularly in the treasury area, while Northern Rock, Halifax (HBOS) and Bradford \& Bingley initially ${ }^{15}$ failed because of diversification on the liabilities side of the balance sheet as they became excessively dependent upon securitisation and wholesale funding. Later it emerged that asset quality at all three institutions was poor.

In Scotland, Airdrie Savings Bank refused to join the amalgamation of regional TSB structures prior to demutualisation and instead remained as a successful mutual; O'Rourke (2009) argues that this shows the opportunity for competition to be restored to the financial sector through a process of remutualising failed financial institutions.

15 Though asset quality problems also then emerged. 


\section{Bibliography}

Ayadi, Rym, Reinhard Schmidt, Santiago Carbo Valverde, Emrah Arbak \& Francesco Fernandez, (2009), Investigating the Diversity in the European Banking Industry: Performance and Role of Savings Banks, Report for the EU Commission, Centre for European Policy Studies, Brussels.

Chaddad, Fabio R. and Michael L. Cook (2004), The Economics of Organization Structure Changes: A US Perspective on Demutualization, Annals of Public and Cooperative Economics, Volume 75, Number 4, pages 575-594

Cook, J., S. Deakin, J. Michie and D. Nash (2003), Trust Rewards: realising the mutual advantage, Mutuo

Cuevas, Carlos E. and Klaus P. Fischer (2006), Co-operative Financial Institutions: Issues in Governance, Regulation, and Supervision, World Bank Working Paper No. 82

Darling, Alastair (2009), 'After Lehmans' fall, we must look beyond the banks', The Observer, September $13^{\text {th }}$, page 28

Drake, L. and Llewellyn, D.T. (2001), 'The Economics of Mutuality: A Perspective on UK Building Societies', in ed. J. Birchall, the New Mutualism in Public Policy, London, Routledge.

Groeneveld, Hans and Bouke de Vries (2009), European co-operative banks: First lessons of the subprime crisis, unpublished paper

Haldane, Andrew G. (2009a), 'Rethinking the Financial Network', Speech delivered at the Financial Student Association, Amsterdam, April

Haldane, Andrew G. (2009b), 'Credit is Trust', Speech delivered at the Association of Corporate Treasurers, Leeds, September $14^{\text {th }}$

Hansmann, Henry (1996), The Ownership of Enterprise, Cambridge, MA: The Belknap Press of Harvard University Press

Hesse, Heiko and Martin Čihák (2007), Co-operative Banks and Financial Stability, International Monetary Fund Working Paper WP/07/2

HM Treasury (2009), Reforming Financial Markets, White Paper, London, July

Kay, John (1991), 'The Economics of Mutuality', Annals of Public and Co-operative Economics, 62, 3, pp. 309-318.

Kay, John (2008), 'The titan's inability to say sorry', Financial Times, $16^{\text {th }}$ December. 
Kay, John (2009), Narrow Banking: the reform of banking regulation, NESTA and Centre for the Study of Financial Innovation, London, September

Llewellyn, D T (2009a), 'The New Banking and Financial System', in New Frontiers in Regulation and Oversight of the Financial System, eds. David Mayes, Robert Pringle and Michael Taylor, Central Banking Publications, London, 2009.

Llewellyn, D T (2009b), 'Financial Innovation and a New Economics of Banking: Lessons from the Financial Crisis', in ed. Sandra Mollentze, Challenges for Monetary Policy in Emerging Markets, report of bi-ennial SARB conderence, South African Reserve Bank, Pretoria.

Llewellyn, D T (2009c), 'Building Societies and the Crisis', Butlers Building Society Guide, London, ICAP plc, May.

Michie, J. and J. Blay (2004), Mutuals and their Communities, Mutuo

O'Rourke, Tony (2009), Banking for the community in an era of financial turmoil Airdrie Savings Bank \& the issue of bank ownership and governance, paper presented to International Co-operative Association Research Conference, Oxford, September

Treasury Select Committee (2009), Banking Crisis: dealing with the failure of the UK banks, $7^{\text {th }}$ Report, $1^{\text {st }}$ May, House of Commons, London: The Stationery Office Limited

Warner, J (2008), The Independent, $7^{\text {th }}$ June. 


\section{List of Authors}

Jonathan Michie is Professor of Innovation and Knowledge Exchange at the University of Oxford where he is Director of the Department for Continuing Education, President of Kellogg College, and Director of the Oxford Centre for Mutual \& Employee-owned Business.

David T Llewellyn is Professor of Money \& Banking at the University of Loughborough and is an Associate of the Oxford Centre for Mutual \& Employee-owned Business.

David Anderson was Chief Executive of Yorkshire Building Society (19962003) and then of Co-operative Financial Services prior to its merger with Britannia Building Society in August 2009.

Nick Eyre is former Group Secretary of the Co-operative Group and before that on the General Counsel and Head of Compliance at Bristol \& West Building Society (1990-1998).

Peter Hunt is Chief Executive of Mutuo and a member of the Management Board of the Oxford Centre for Mutual \& Employee-owned Business.

Cliff Mills is a Consultant to Mutuo.

Jeremy Palmer is Head of Financial Policy at the Building Societies Association, having previously worked for the Building Societies Commission and then the Financial Services Authority. 


\section{Acknowledgements}

The issues covered by this Report were discussed at a specially convened meeting of the Oxford Centre for Mutual \& Employee-owned Business on June $15^{\text {th }} 2009$. I am most grateful to all those who took part in that meeting, and who contributed material for discussion beforehand and subsequently, including David Anderson who was then Chief Executive of Co-operative Financial Services; Matthew Ball of Mutuo; William Davies, then of Demos and now of the Saïd Business School; Francis Davis of Las Casas Institute, Blackfriars Hall, Oxford; Nick Eyre, Former Group Secretary of the Cooperative Group; Joe Hewitt, Project Researcher; Peter Hunt, Chief Executive of Mutuo; Professor Colin Mayer, Dean of the Saïd Business School; Cliff Mills, a Consultant to Mutuo; Jeremy Palmer, Head of Financial Policy at the Building Societies Association; and Simon Phillips, Partner, Mergers \& Acquisitions, Slaughter \& May.

All the above are in effect co-authors of this Report, but the written contributions came primarily from David Llewellyn, David Anderson, Nick Eyre, Peter Hunt, Cliff Mills and Jeremy Palmer, who are therefore named as the co-authors. Particular thanks and acknowledgement has to go to Professor Llewellyn who provided a detailed background paper for the June meeting which not only helped to guide and focus discussion but also makes up much of this Report. Kate Barker of the Bank of England's Monetary Policy Committee; Peter Jeffrey and David Roper, both Partners at PWC; and Ian Snaith, Senior Lecturer in Law at the University of Leicester, also provided thoughtful and helpful advice.

I am most grateful to Sandra Gee and Henriette Lundgren for their hard work in organising the June meeting in Oxford.

I am also grateful for discussions with and material supplied by participants at the International Co-operative Alliance Research Conference, Oxford, September 2009, and in particular Tony O'Rourke, author of the paper on 'Banking for the community in an era of financial turmoil - Airdrie Savings Bank \& the issue of bank ownership and governance'. I am likewise grateful for comments from participants at the International Social Innovation Research Conference hosted by the Skoll Centre for Social Entrepreneurship at the Saïd Business School in September 2009, especially Dr Alex Nichols.

Jonathan Michie

Oxford

September $21^{\text {st }} 2009$ 


\section{About the Oxford Centre for Mutual and Employee-owned Business}

The Centre is based at Kellogg, one of Oxford University's graduate colleges. Kellogg College supports the lifelong learning work of the University, giving opportunities for the continuing education and professional development of mature and part-time students. A wide range of teaching rooms and conference facilities, including a newly built dining hall, bar, common room and library are available at Kellogg College. The College is closely associated with the Oxford University Department for Continuing Education.

Policy makers, academics and citizens more generally are showing increasing interest in the participatory approach to stakeholder involvement created by co-owned and mutual enterprise. Sea changes in the UK and global economies have reinforced the importance of the mutual and co-owned business sectors, with their high standards of corporate ethics and community responsibility and long-term sustainable strategies. This changed environment offers an unprecedented opportunity for thought leadership, provided it is empirically based, grounded in world-class research and analysis, and validated through a rigorous curriculum reflective of the sectors' performance needs.

The principal activities of the Oxford Centre for Mutual and Employee-owned Business are thus research and professional development via tailored short courses and educational programmes focused on the business needs of the mutual and co-owned sectors. With a commitment to applied knowledge and dissemination, the Centre runs conferences, seminars and guest lectures and promotes networking and partnering within and beyond Oxford. The aims of the Centre are to:

i. Provide research into the performance of the mutual and co-owned sectors

ii. Deliver a curriculum that is closely matched to the needs of relevant businesses and the development of their current and future leaders

iii. Encourage debate and advance new thinking about mutuality and co-ownership

iv. Create a national and international network of academics, practitioners and policy makers

\section{Governance}

The Centre is supported by the member organisations for co-owned and mutual businesses in the UK - Mutuo and the Employee Ownership Association. The Centre's first corporate sponsor is Simplyhealth.

Mutuo brings together the different wings of the mutual sector to promote a better understanding of mutuals and to encourage mutual approaches to business and public policy. Through Mutuo, consumer co-operatives, building societies, mutual insurers and friendly societies and other mutuals work together to promote their shared interests to the Government, media and other decision makers. Since 2001, Mutuo has worked to promote new mutuals. This has led to renewed growth in the mutual sector, with public sector mutuals established in health, housing and education and new community based 
businesses ranging from football to childcare, with a total mutual sector now turning over $£ 84$ billion each year.

The Employee Ownership Association is the voice of co-owned business in the UK. It is the business association for companies who are substantially or wholly owned by the people who work for them. Its members include the John Lewis Partnership, Arup, Unipart, Mott MacDonald, Blackwell, Martin Currie, eaga and Baxi Partnership; long established co-owned companies like Scott Bader and Tullis Russell; and a diverse range of other successful enterprises. The Employee Ownership Association represents a thriving sector worth around $£ 25$ billion annually and growing.

Previously known as HSA, BCWA, HealthSure, LHF and Totally Active, the family of businesses has joined together over the last eight years to form Simplyhealth. Since Simplyhealth doesn't have shareholders they can concentrate on being the best health company they can be; all their profits are reinvested into the business.

To receive information of upcoming events and publications, please contact us at:

The Oxford Centre for Mutual and Employee-owned Business

\author{
Kellogg College \\ 62 Banbury Road \\ Oxford OX2 6PN, UK \\ tel: +441865612029 \\ fax: +44 1865612001 \\ email: meob@kellogg.ox.ac.uk
}

or visit our website:

www.kellogg.ox.ac.uk/researchcentres/meob.php 